\title{
EFEKTIFITAS PRENATAL YOGA TERHADAP PENGURANGAN KETIDAKNYAMANAN DALAM KEHAMILANTRIMESTER III DI KLINIK PRATAMA ASIH WALUYO JATI
}

The Effectiveness of Prenatal Yoga on Reducing the Inconvenience in The ThirdTrimester Pregnancy at Asih Waluyo Jati Clinic

Dheska Arthyka Palifiana ${ }^{1}$, Nur Khasanah ${ }^{2}$, Ratih Kumoro Jati ${ }^{3}$

${ }^{12}$ Universitas Respati Yogyakarta, ${ }^{3}$ Universitas Jenderal Ahmad Yani Yogyakarta (dheska87@gmail.com)

\begin{abstract}
ABSTRAK
Latar Belakang :Periode yang membutuhkan perhatian khusus selama kehamilan adalah trimester III, masa ini merupakan masa terjadi pertumbuhan dan perkembangan janin yang semakin meningkat. Berat badan yang meningkat drastic menyebabkan ibu hamil merasa cepat lelah, sukar tidur, nafas pendek, kaki dan tangan bengkak.Hal ini menyebabkan ibu merasakan rasa pegal pada pinggang, varises dan kram pada kaki. Ibu hamil trimester III juga mengalami kesulitan untuk tidur dikarenakan berbagai macam keluhan yang timbul selama kehamilan sehingga mengakibatkan kualitas tidur yang buruk. Ketidaknyamanan kehamilan dan peningkatan kualitas tidur bisa diatasi dengan melakukan prenatal yoga.

Tujuan:Mengetahui Efektifitas Prenatal Yoga terhadap Pengurangan Ketidaknyamanan dalam Kehamilan Trimester III di Klinik Pratama Asih Waluyo Jati.

Metode :Jenis penelitian quasi experimentwith two group pre-test post-test with control. Jumlah sampel 40 ibu hamil trimester III dengan kelompok kasus $20 \mathrm{ibu}$ hamil yang melakukan prenatal yoga sebanyak enam kali dan kelompok control $20 \mathrm{ibu}$ hamil yang tidak melakukan prenatal yoga. Analisis data bivariate menggunakan uji Wilcoxon dan uji Chisquare sedangkan analisis multivariate menggunakan uji regresi.

Hasil:Ada pengaruh prenatal yoga terhadap kualitas tidur $(0,002<0,005)$, nyeri pinggang $(0,001<0,005)$, nyeri symphysis pubis $(0,000<0,005)$, oedema $(0,004<0,005)$, jenis persalinan $(0,038<0,005)$. Variabel yang paling dominan dari pengaruh yoga terhadap ketidaknyamanan dalam kehamilan trimester III adalah nyeri symphisis pubis (OR 6,030).

Kesimpulan :Ada Pengaruh Prenatal Yoga terhadap Kualitas Tidur, Nyeri Pinggang, Nyeri Symphisis Pubis, Oedema, dan Jenis Persalinan pada Ibu Hamil Trimester III. Variabel yang paling dominan dari Pengaruh Prenatal Yoga terhadap Ketidaknyamanan dalam Kehamilan Trimester III adalah Nyeri Symphisis Pubis.
\end{abstract}

Kata Kunci: Prenatal Yoga, Kualitas Tidur, Nyeri Pinggang, Symphisis Pubis, Bengkak 


\begin{abstract}
Background:The period that requires special attention during pregnancy is the third trimester, during this time, there is significant fetal growth and development. Drastic weight gain can cause pregnant women to experience feeling tired quickly, sleeping difficulty, shortness of breath, and swelling on feet and hands.This may cause the mothers to experience aches in their waist, varicose veins, and cramps in the legs. Pregnant women in the third trimester also experience sleeping difficulty due to various complaints during pregnancy which results in poor sleep quality. The inconvenience during pregnancy and the decrease in sleep quality can be resolved by doing prenatal yoga.

The Aim :This study aimed to find out the effectiveness of prenatal yoga on reducing the inconvenience in the third-trimester pregnancy at Asih Waluyo Jati Clinic.

Method:The type of this study was a quasi-experiment using two pretest-posttestcontrol groups design. Total samples was 40 third-trimester pregnant women. Those samples were divided into two groups, namely the case group consisted of 20 pregnant women who did prenatal yoga for six times and control group consisted of 20 pregnant women who did not do prenatal yoga. Then, the data were analyzed using bivariate analysis with the Wilcoxon test and the chi-squared test and using multivariate analysis with the regression test.

Results:showed that prenatal yoga had an effect on sleep quality $(0.002<0.005)$; low back pain $(0.001<0.005)$; symphysis pubis pain $(0.000<0.005)$; edema $(0.004<0.005)$; childbirth process $(0.038<0.005)$. The most dominant variable from prenatal yoga effect on the inconvenience in the third-trimester pregnancy was the symphysis pubis pain (OR 6.030).

Conclusion :prenatal yoga had an effect on sleep quality, low back pain, symphysis pubis pain, edema, and the type of childbirth process for third trimester pregnant women. The most dominant variable from prenatal yoga effect on the inconvenience in the third-trimester pregnancy was the symphysis pubis pain.
\end{abstract}

Keywords: Prenatal Yoga, Sleep Quality, Low Back Pain, Symphysis Pubis, Edema

\title{
PENDAHULUAN
}

Dalam masa kehamilan wanita sering mengalami banyak perubahan, baik perubahan fisik maupun perubahan psikologis. Perubahan itu akan terus terjadi selama Sembilan bulan masa kehamilannya, kondisi tersebut akan senantiasa menimbulkan rasa ketidaknyamanan pada fisik ibu hamil (Fauziah, 2016). Berat badan yang meningkat drastic menyebabkan ibu hamil merasa cepat lelah, sukar tidur, nafas pendek, kaki dan tangan oedema (Hamilton, 2010). Peningkatan tinggi fundus uteri yang disertai pembesaran perut, membuat tubuh lebih di depan. Dalam upaya menyesuaikan dengan beban tubuh yang berlebihan sehingga tulang belakang mendorong ke arah belakang, mendorong postur tubuh lordosis. Hal ini menyebabkan ibu merasakan rasa pegal pada pinggang, varises dan kram pada kaki (Bobak, 2010). Menurut Jurnal Community Practicioner ibu hamil

Efektifitas Prenatal Yoga Terhadap Pengurangan Ketidaknyamanan Dalam 
mengalami permasalahan ketidaknyamanan selama kehamilan seperti masalah sensasi penuh pada hidung akibat peningkatan hormone progesterone, peregangan ligament terutama pada daerah pubis yang menyebabkan nyeri symphysis pubis, ketidaknyamanan tersebut tentunya akan berdampak pada status kesehatan wanita selama kehamilan (Community, 2011).

Salah satu ketidaknyamanan kehamilan adalah bengkak pada kaki, bengkak fisiologis pada kaki timbul akibat gangguan sirkulasi vena dan peningkatan tekanan darah pada ekstremitas bawah. Gangguan sirkulasi ini disebabkan oleh uterus yang membesar menakan vena panggul saat ibu hamil duduk atau berdiri dan pada vena kava inferior saat berada dalam posisi telentang (Varney, 2011). Dalam masa kehamilan hampir semua wanita hamil mengalami kesulitan dalam memenuhi kebutuhan tidur yang optimal (Wainright, 2012). Hal tersebut terjadi karena perubahan-perubahan yang dialami ibu hamil hamil. Seiring dengan bertambahnya usia kehamilan keluhan yang diakibatkan oleh pembesaran perut, perubahan anatomis dan perubahan hormonal akan menyebabkan munculnya keluhan pada ibu hamil (Venkata, 2010). Kesulitan dalam pemenuhan tidur dapat membuat kondisi ibu hamil menurun, konsentrasi berkurang, mudah lelah, badan terasa pegal, tidak mood bekerja dan cenderung emosional, tentu saja hal ini dapat membuat beban kehamilan semakin berat (Wainright, 2012).

Salah satu perawatan untuk mengurangi ketidaknyamanan kehamilan adalah olahraga, untuk ibu hamil olahraga yang dianjurkan adalah prenatal yoga. Prenatal yoga merupakan olahraga yang berfungsi mempersiapkan persalinan karena tehnik latihannya menitikberatkan pada kelenturan otot jalan lahir, teknik pernapasan, relaksasi dan ketenangan pikiran ibu selama kehamilan dan untuk menghadapi persalinan (Field, 2010).

Berdasarkan latar belakang diatas, penulis tertarik untuk melakukan penelitian tentang "Efektifitas Prenatal Yoga terhadap Pengurangan Ketidaknyamanan dalam Kehamilan Trimester III di Klinik Pratama Asih Waluyo Jati". Sehingga dapat mengurangi keluhan ketidaknyamanan kehamilan pada ibu hamil terutama trimester III.

\section{METODE PENELITIAN}

Jenis penelitian ini adalah quasi experiment with two group pre-test post-test with control. Penelitian di lakukan di Klinik Pratama Asih Waluyo Jati dengan tehnik sampling purposive sampling. Populasi dalam penelitian ini adalah $40 \mathrm{ibu}$ hamil trimester III dengan kelompok perlakuan20 ibu hamil trimester III yang melakukan prenatal yoga, sedangkan kelompok control 20 ibu hamil trimester III yang tidak melakukan prenatal yoga. Waktu pengambilan data dilakukan pada bulan April sampai bulan Juli 2019, untuk kelompok perlakuan dilakukan prenatal yoga selama 6 kali (setiap hari minggu) dengan durasi 2 jam yang dipandu oleh fasilitator prenatal yoga yang sudah tersertifikasi sedangkan untuk kelompok control pengambilan data dilakukan pada kunjungan awal saat pemeriksaan kehamilan dan kunjungan ulang saat sudah 6 kali kunjungan yang dibantu oleh bidan pelaksana di Klinik Pratama Asih Waluyo Jati. Pengambilan data menggunakan kusioner Numeric Rating Scale untuk mengukur nyeri pinggang 
dan nyeri Symphisis pubis, kuisioner The ;Pittsburgh Sleep Quality Index (PSQI) untuk mengukur kualitas tidur, checklist pitting oedema untuk mengukur bengkak kaki, dan checklist jenis persalinan. Analisis data yang digunakan adalah bivariate menggunakan uji Wilcoxon dan uji chisquare dan analisis multivariate menggunakan uji regresi.

\section{HASIL DAN PEMBAHASAN}

\section{Hasil}

Tabel 1. Kualitas Tidur Ibu Hamil Trimester III pada Kelompok Perlakuan dan Kelompok Kontrol

\begin{tabular}{lcccccccc}
\hline $\begin{array}{c}\text { Kualitas } \\
\text { Tidur }\end{array}$ & \multicolumn{3}{c}{ Kelompok Perlakuan } & \multicolumn{3}{c}{ Kelompok Kontrol } \\
& \multicolumn{2}{c}{ Pre } & \multicolumn{2}{c}{ Post } & \multicolumn{2}{c}{ Pre } & \multicolumn{2}{c}{ Post } \\
& $\mathrm{n}$ & $\%$ & $\mathrm{n}$ & $\%$ & $\mathrm{n}$ & $\%$ & $\mathrm{n}$ & $\%$ \\
\hline Baik & 4 & 20 & 16 & 80 & 3 & 15 & 5 & 25 \\
Buruk & 16 & 80 & 4 & 20 & 17 & 85 & 15 & 75 \\
Total & 20 & 100 & 20 & 100 & 20 & 100 & 20 & 100 \\
\hline
\end{tabular}

Berdasarkan tabel 1dapat diketahui bahwa kualitas tidur ibu hamil trimester III pada kelompok perlakuan (prenatal yoga) yang semula kualitas tidurnya sebagian besar dalam kategori buruk sebesar $80 \%$ setelah mengikuti prenatal yoga sebanyak enam kali kualitas tidurnya meningkat menjai baik sebesar $80 \%$. Sedangkan pada kelompok control (tidak prenatal yoga) sebagian besar kualitas tidur ibu hamil pada kunjungan adalah buruk sebesar 85\% dan setelah dilakukan pengukuran ulang pada kunjungan ke enam sebagian besar kualitas tidur baik sebesar $75 \%$.

Tabel 2. Nyeri Pinggang Ibu Hamil pada Kelompok Perlakuan dan Kelompok Kontrol

\begin{tabular}{lcccccccc}
\hline \multicolumn{1}{c}{ Nyeri Pinggang } & \multicolumn{3}{c}{ Kelompok Perlakuan } & \multicolumn{3}{c}{ Kelompok Kontrol } \\
& \multicolumn{2}{c}{ Pre } & \multicolumn{2}{c}{ Post } & \multicolumn{2}{c}{ Pre } & \multicolumn{2}{c}{ Post } \\
& $\mathrm{N}$ & $\%$ & $\mathrm{n}$ & $\%$ & $\mathrm{n}$ & $\%$ & $\mathrm{n}$ & $\%$ \\
\hline Tidak Nyeri & 0 & 0 & 2 & 10 & 0 & 0 & 0 & 0 \\
Nyeri Ringan & 3 & 15 & 10 & 50 & 1 & 5 & 2 & 10 \\
Nyeri Sedang & 10 & 50 & 6 & 30 & 12 & 60 & 10 & 50 \\
Nyeri Berat & 7 & 35 & 2 & 10 & 8 & 40 & 8 & 40 \\
Total & 20 & 100 & 20 & 100 & 20 & 100 & 20 & 100 \\
\hline
\end{tabular}

Berdasarkan tabel 2dapat diketahui bahwa pada kelompok perlakuan (prenatal yoga) sebagian besar nyeri pinggang ibu hamil dalam kategori nyeri sedang sebesar $50 \%$ dan setelah melakukan prenatal yoga selama enam kali intensitas nyeri pinggang pada ibu sebagian besar dalam kategori nyeri ringan sebesar $50 \%$. Pada kelompok control (tidak prenatal yoga) sebagian besar ibu hamil mengalami nyeri pinggang dalam kategori nyeri sedang $60 \%$ pada kunjungan awal dan setelah dilakukan pengukuran ulang pada kunjungan ke enam 
didapatkan bahwa sebagian besar ibu hamil mengalami nyeri pinggang dalam kategori sedang sebesar $50 \%$.

Tabel 3. Nyeri Symphisis Pubis Ibu Hamil pada Kelompok Perlakuan dan Kelompok Kontrol

\begin{tabular}{lcccccccc}
\hline \multicolumn{1}{c}{$\begin{array}{c}\text { Nyeri Symphisis } \\
\text { Pubis }\end{array}$} & \multicolumn{3}{c}{ Kelompok Perlakuan } & \multicolumn{3}{c}{ Kelompok Kontrol } \\
& $\mathrm{N}$ & \multicolumn{2}{c}{ Pre } & \multicolumn{2}{c}{ Post } & \multicolumn{2}{c}{ Pre } & \multicolumn{2}{c}{ Post } \\
& & & $\mathrm{n}$ & $\%$ & $\mathrm{n}$ & $\%$ & $\mathrm{n}$ & $\%$ \\
\hline Tidak Nyeri & 0 & 0 & 9 & 45 & 0 & 0 & 0 & 0 \\
Nyeri Ringan & 9 & 45 & 7 & 35 & 0 & 0 & 2 & 10 \\
Nyeri Sedang & 7 & 35 & 2 & 10 & 11 & 55 & 12 & 60 \\
Nyeri Berat & 4 & 20 & 2 & 10 & 9 & 45 & 6 & 30 \\
Total & 20 & 100 & 20 & 100 & 20 & 100 & 20 & 100 \\
\hline
\end{tabular}

Berdasarkan tabel 3 dapat diketahui bahwa pada kelompok perlakuan (prenatal yoga) sebagian besar ibu hamil mengalami nyeri symphysis pubis dalam kategori nyeri ringan sebesar $45 \%$ dan setelah melakukan prenatal yoga sebanyak enam kali sebagian besar ibu tidak mengalami nyeri symphysis pubis sebesar $45 \%$. Pada kelompok control sebagian besar ibu hamil mengalami nyeri symphysis pubis dalam kategori nyeri sedang sebesar 55\% pada kunjungan awal dan setelah dilakukan pengukuran ulang pada kunjungan ke enam sebagian besar ibu hamil mengalami nyeri symphysis pubis dalam kategori sedang sebanyak $60 \%$.

Tabel 4. Oedema pada Ibu Hamil Kelompok Perlakuan dan Kelompok Kontrol

\begin{tabular}{lcccccccc}
\hline \multicolumn{1}{c}{ Oedema } & \multicolumn{3}{c}{ Kelompok Perlakuan } & \multicolumn{3}{c}{ Kelompok Kontrol } \\
& \multicolumn{2}{c}{ Pre } & \multicolumn{2}{c}{ Post } & \multicolumn{2}{c}{ Pre } & \multicolumn{2}{c}{ Post } \\
& $\mathrm{N}$ & $\%$ & $\mathrm{n}$ & $\%$ & $\mathrm{n}$ & $\%$ & $\mathrm{n}$ & $\%$ \\
\hline Derajat 1 & 0 & 0 & 16 & 80 & 1 & 5 & 6 & 30 \\
Derajat 2 & 14 & 70 & 2 & 35 & 7 & 35 & 7 & 35 \\
Derajat 3 & 5 & 25 & 1 & 10 & 9 & 45 & 6 & 30 \\
Derajat 4 & 1 & 5 & 1 & 10 & 3 & 15 & 1 & 5 \\
Total & 20 & 100 & 20 & 100 & 20 & 100 & 20 & 100 \\
\hline
\end{tabular}

Berdasarkan tabel 4 dapat diketahui bahwa pada kelompok perlakuan (prenatal yoga) sebagian besar ibu hamil mengalami oedema derajat 2 sebanyak $70 \%$ dan setelah melakukan prenatal yoga selama enam kali sebagian besar ibu hamil mengalami oedema derajat 1 sebesar $80 \%$. Pada kelompok control sebagian besar ibu hamil mengalami oedema derajat 3 sebesar $45 \%$ pada kunjungan awal dan setelah dilakukan pengukuran ulang pada kunjungan ke enam sebagian besar ibu hamil mengalami oedema derajat 2 sebesar $35 \%$. 
Tabel 5. Jenis Persalinan Ibu Kelompok Perlakuan dan Kelompok Kontrol

\begin{tabular}{lcccc}
\hline \multirow{2}{*}{ Jenis Persalinan } & \multicolumn{2}{c}{ Kelompok Perlakuan } & \multicolumn{2}{c}{ Kelompok Kontrol } \\
& $\mathrm{n}$ & $\%$ & $\mathrm{n}$ & $\%$ \\
\hline Normal & 17 & 85 & 11 & 55 \\
Tindakan & 3 & 15 & 9 & 45 \\
Total & 20 & 100 & 20 & 100 \\
\hline
\end{tabular}

Berdasarkan tabel 5 dapat diketahui bahwa pada kelompok ibu yang melakukan prenatal yoga sebagian besar jenis persalinannya adalah normal atau spontan sebesar $85 \%$, sedangkan pada kelompok ibu yang tidak melakukan prenatal yoga ibu yang mempunyai jenis persalinan normal atau spontan sebesar $55 \%$.

Tabel 6. Analisa Bivariat Pengaruh Prenatal Yoga terhadap Kualitas Tidur Ibu Hamil Trimester III

\begin{tabular}{lccccccc}
\hline \multirow{2}{*}{ Prenatal Yoga } & \multicolumn{3}{c}{ Kualitas Tidur } & \multicolumn{2}{c}{ Total } & P-Value \\
& $\mathrm{N}$ & $\%$ & $\mathrm{n}$ & $\%$ & $\mathrm{n}$ & $\%$ & \\
\hline Melakukan & 16 & 80 & 4 & 20 & 20 & 50 & 0,002 \\
Tidak Melakukan & 5 & 25 & 15 & 75 & 20 & 50 & \\
Jumlah & 21 & 52,5 & 19 & 47,5 & 40 & 100 & \\
\hline
\end{tabular}

Berdasarkan tabel 6 dapat diketahui bahwa dari ibu yang melakukan prenatal yoga sebagian besar mempunyai kualitas tidur baik sebanyak $80 \%$ sedangkan ibu yang tidak melakukan prenatal yoga sebagian besar mempunyai kualitas tidur buruk sebanyak 75\%. Hasil analisis menunjukkan p-value 0,002 yang berarti ada pengaruh prenatal yoga terhadap kualitas tidur ibu hamil trimester III.

Tabel 7. Analisa Bivariat Pengaruh Prenatal Yoga terhadap Nyeri Pinggang Ibu Hamil Trimester III

\begin{tabular}{|c|c|c|c|c|c|c|c|c|c|c|c|}
\hline \multirow{3}{*}{$\begin{array}{l}\text { Prenatal } \\
\text { Yoga }\end{array}$} & \multicolumn{10}{|c|}{ Nyeri Pinggang } & \multirow{3}{*}{ P-Value } \\
\hline & \multicolumn{2}{|c|}{$\begin{array}{l}\text { Tidak } \\
\text { Nyeri }\end{array}$} & \multicolumn{2}{|c|}{ Ringan } & \multicolumn{2}{|c|}{ Sedang } & \multicolumn{2}{|c|}{ Berat } & \multicolumn{2}{|c|}{ Total } & \\
\hline & $\mathrm{n}$ & $\%$ & $\mathrm{~N}$ & $\%$ & $\mathrm{n}$ & $\%$ & $\mathrm{n}$ & $\%$ & $\mathrm{n}$ & $\%$ & \\
\hline Melakukan & 2 & 10 & 10 & 50 & 6 & 30 & 2 & 10 & 20 & 50 & \\
\hline Tidak & 0 & 0 & 2 & 10 & 10 & 50 & 8 & 40 & 20 & 50 & 0,001 \\
\hline Melakukan & & & & & & & & & & & \\
\hline Jumlah & 2 & 5 & 12 & 30 & 16 & 40 & 10 & 25 & 40 & 100 & \\
\hline
\end{tabular}

Berdasarkan tabel 7 dapat diketahui bahwa dari 20 ibu hamil yang melakukan prenatal yoga sebanyak $10 \mathrm{ibu}(50 \%)$ mengalami nyeri pinggang dalam kategori nyeri ringan, sedangkan dari $20 \mathrm{ibu}$ hamil yang tidak melakukan prenatal yoga sebanyak $10 \mathrm{ibu}(50 \%)$ mengalami nyeri pinggang dalam kategori nyeri sedang. Hasil analisis menunjukkan p-value 0,001 yang berarti ada pengaruh prenatal yoga terhadap nyeri pinggang ibu hamil trimester III. 
Tabel 8. Analisa Bivariat Pengaruh Prenatal Yoga terhadap Nyeri Symphisis Pubis Ibu Hamil Trimester III

\begin{tabular}{|c|c|c|c|c|c|c|c|c|c|c|c|}
\hline \multirow{4}{*}{$\begin{array}{l}\text { Prenatal } \\
\text { Yoga }\end{array}$} & \multicolumn{10}{|c|}{ Nyeri Symphisis Pubis } & \multirow{4}{*}{$\begin{array}{l}\text { P- } \\
\text { Value }\end{array}$} \\
\hline & \multirow{2}{*}{\multicolumn{2}{|c|}{$\begin{array}{l}\text { Tidak } \\
\text { Nyeri }\end{array}$}} & \multirow{2}{*}{\multicolumn{2}{|c|}{ Ringan }} & \multirow{2}{*}{\multicolumn{2}{|c|}{ Sedang }} & \multirow{2}{*}{\multicolumn{2}{|c|}{ Berat }} & \multirow{2}{*}{\multicolumn{2}{|c|}{ Total }} & \\
\hline & & & & & & & & & & & \\
\hline & $\mathrm{n}$ & $\%$ & $\mathrm{~N}$ & $\%$ & $\mathrm{n}$ & $\%$ & $\mathrm{n}$ & $\%$ & $\mathrm{n}$ & $\%$ & \\
\hline Melakukan & 9 & 45 & 6 & 35 & 2 & 10 & 2 & 10 & 20 & 50 & \\
\hline Tidak & 0 & 0 & 2 & 10 & 12 & 60 & 6 & 30 & 20 & 50 & 0,000 \\
\hline Melakukan & & & & & & & & & & & \\
\hline Jumlah & 9 & 22,5 & 8 & 20 & 14 & 35 & 8 & 20 & 40 & 100 & \\
\hline
\end{tabular}

Berdasarkan tabel 8 dapat diketahui pada 20 ibu hamil yang melakukan prenatal yoga sebanyak 9 ibu hamil (45\%) tidak mengalami nyeri symphysis pubis, sedangkan 20 ibu hamil yang tidak melakukan prenatal yoga sebanyak 12 ibu (60\%) mengalami nyeri symphysis pubis dalam kategori nyeri sedang. Hasil analisis menunjukkan p-value 0,000 yang berarti ada pengaruh prenatal yoga terhadap nyeri symphysis pubis ibu hamil trimester III.

Tabel 9. Analisa Bivariat Pengaruh Prenatal Yoga terhadap Oedema (Bengkak) pada Ibu Hamil Trimester III

\begin{tabular}{|c|c|c|c|c|c|c|c|c|c|c|c|}
\hline \multirow{3}{*}{$\begin{array}{l}\text { Prenatal } \\
\text { Yoga }\end{array}$} & \multirow{2}{*}{\multicolumn{2}{|c|}{ Derajat 1}} & \multirow{2}{*}{\multicolumn{2}{|c|}{ Derajat 2}} & \multicolumn{2}{|c|}{ Oedema } & \multirow{2}{*}{\multicolumn{2}{|c|}{ Derajat 4}} & \multirow{2}{*}{\multicolumn{2}{|c|}{ Total }} & \multirow{3}{*}{$\begin{array}{l}\text { P- } \\
\text { Value }\end{array}$} \\
\hline & & & & & & at 3 & & & & & \\
\hline & $\mathrm{n}$ & $\%$ & $\mathrm{~N}$ & $\%$ & $\mathrm{n}$ & $\%$ & $\mathrm{n}$ & $\%$ & $\mathrm{n}$ & $\%$ & \\
\hline Melakukan & 16 & 80 & 2 & 10 & 1 & 5 & 1 & 5 & 20 & 50 & \\
\hline $\begin{array}{l}\text { Tidak } \\
\text { Melakukan }\end{array}$ & 6 & 30 & 7 & 35 & 6 & 30 & 1 & 5 & 20 & 50 & 0,000 \\
\hline Jumlah & 22 & 55 & 9 & 22,5 & 7 & 17,5 & 2 & 5 & 40 & 100 & \\
\hline
\end{tabular}

Berdasarkan tabel 9 dapat diketahui bahwa dari 20 ibu hamil yang melakukan prenatal yoga sebanyak 16 ibu (80\%) mengalami oedema derajat 1 , sedangkan dari $20 \mathrm{ibu}$ hamil yang tidak melakukan prenatal yoga sebanyak $7 \mathrm{ibu}$ (35\%) mengalami oedema derajat 2. Hasil analisis menunjukkan p-value 0,004 yang berarti ada pengaruh prenatal yoga terhadap oedema pada ibu hamil trimester III.

Tabel 10. Analisa Bivariat Pengaruh Prenatal Yoga terhadap Jenis Persalinan Ibu

\begin{tabular}{|c|c|c|c|c|c|c|c|}
\hline \multirow{3}{*}{ Prenatal Yoga } & \multicolumn{4}{|c|}{ Jenis Persalinan } & \multirow{2}{*}{\multicolumn{2}{|c|}{ Total }} & \multirow{3}{*}{$\begin{array}{l}\text { P- } \\
\text { Value }\end{array}$} \\
\hline & \multicolumn{2}{|c|}{ Normal } & \multicolumn{2}{|c|}{ Tindakan } & & & \\
\hline & $\mathrm{n}$ & $\%$ & $\mathrm{n}$ & $\%$ & \multicolumn{2}{|c|}{$\mathrm{n} \quad 0$} & \\
\hline Melakukan & 17 & 42,5 & 3 & 7,5 & 20 & 50 & \\
\hline Tidak Melakukan & 11 & 27,5 & 9 & 22,5 & 20 & 50 & 0,038 \\
\hline Jumlah & 28 & 70,0 & 12 & 30,0 & 40 & 100 & \\
\hline
\end{tabular}

Berdasarkan tabel 10 dapat diketahui bahwa dari 20 ibu hamil yang melakukan prenatal yoga sebanyak $17 \mathrm{ibu}(42,5 \%)$ jenis persalinannya normal (spontan), sedangkan dari $20 \mathrm{ibu}$ hamil yang tidak melakukan prenatal yoga 
sebanyak $11 \mathrm{ibu}(27,5 \%)$ jenis persalinannya normal. Hasil penelitian didapatkan 0,038 yang berarti ada pengaruh prenatal yoga terhadap jenis persalinan ibu.

Tabel 11. Analisis Multivariat

\begin{tabular}{lcccc}
\hline \multicolumn{2}{c}{ Variabel } & P-Value & OR & $95 \%$ CI \\
\hline $\begin{array}{l}\text { Nyeri } \\
\text { Pubis }\end{array}$ & Symphisis & 0,001 & 6.030 & $2.75-17.519$ \\
\hline
\end{tabular}

Berdasarkan hasil analisis multivariate ternyata variabel yang paling dominan dari pengaruh prenatal yoga terhadap ketidaknyamanan dalam kehamilan trimester III adalah variabel Nyeri Symphisis Pubis, hasil analisis didapatkan Odss Ratio (OR) dari variabel nyeri symphysis pubis responden 6.030 artinya bahwa ibu yang tidak melakukan prenatal yoga kemungkinan mengalami nyeri symphysis pubis 6 kali lipat dibandingkan ibu yang melakukan prenatal yoga.

\section{Pembahasan}

Berdasarkan Tabel 1. diketahui bahwa pada kelompok ibu yang melakukan prenatal yoga terjadi peningkatan kualitas tidur. Pada pengukuran awal ibu hamil yang mempunyai kualitas tidur baik hanya sebanyak $20 \%$ dan setelah diberikan prenatal yoga selama enam kali terjadi peningkatan kualitas tidur yang baik pada ibu hamil menjadi $80 \%$. Sedangkan pada kelompok ibu yang tidak melakukan prenatal yoga pada pengukuran awal ibu hamil yang mempunyai kualitas tidur baik sebesar $15 \%$ dan setelah dilakukan pengukuran ulang pada kunjungan ke enam hanya terjadi peningkatan sebesar $25 \%$ ibu hamil yang mempunyai kualitas tidur baik.Ibu hamil memerlukan sekitar delapan jam untuk tidur di malam hari, selain itu tidur siang juga dibutuhkan oleh ibu hamil. Kesulitan dalam pemenuhan istirahat tidur dapat membuat kondisi ibu hamil menururn, konsentrasi berkurang, mudah lelah, badan terasa pegal, tidak mood bekerja dan cenderung emosional. Ibu hamil terutama bila sudah memasuki trimester III memerlukan istirahat seperti duduk dan bersantai di sela-sela melakukan kegiatan rutinnya. Ketika memasuki trimester III semakin banyak keluhan-keluhan yang dirasakan ibu sehingga akan menggangu istirahat dan tidur (Field, 2010). Menurut National Sleep Foundation (2017) Salah satu alasan terjadinya kelelahan dan masalah tidur selama hamil adalah perubahan kadar hormone, meningkatnya kadar progesterone menyebabkan kantuk di siang hari yang berlebihan, terutama pada trimester pertama. Perubahan hormone dan fisik selama kehamilan dapat menyebabkan perubahan pada tidur dan kualitas tidur (Yucel, 2012). Factor psikologis juga mempunyai pengaruh penting terhadap kemampuan untuk bisa memulai dan mempertahankan tidur. Kecemasan dan depresi yang dialami seseorang dapat mengganggu pola tidur. Stress emosional dapat menyebabkan seseorang menjadi tegang dan seringkali mengarah frekuensi ketika tidak bisa tidur (Potter, 2010).

Tabel 2. diketahui pada kelompok ibu yang melakukan prenatal yoga pada saat pengukuran awal diperoleh bahwa nyeri pinggang ibu sebagian besar dalam kategori nyeri sedang sebanyak 50\% dan setelah melakukan prenatal yoga selama enak kali diperoleh hasil bahwa sebagian besar ibu hamil berubah mengalami nyeri ringan sebanyak 50\%. Sedangkan pada kelompok ibu yang tidak melakukan 
prenatal yoga pada saat pengukuran awal diperoleh bahwa nyeri pinggang ibu sebagian besar dalam kategori sedang sebanyak $60 \%$ dan setelah dilakukan pengukuran ulang dalam waktu enam kali kunjungan kehamilan diperoleh bahwa nyeri pinggang ibu sebagian besar tetap dalam kategori sedang sebanyak $50 \%$.Nyeri pinggang umumnya terjadi di trimester III diakibatkan beban di perut serta karena tulang pinggang bagian bawah terutama di daerah pinggul tulang belakang membengkok dan ligament meregang. Inilah yang membuat pinggang ibu hamil sering pegal bahkan terasa nyeri. Disamping meningkatnya kadar hormone juga membuat tulang rawan pada sendi melunak, sehingga kelenturannya berkurang dan timbullah sakit pinggang. Pada ibu hamil terjadi perubahan bodi mekanik sehubungan dengan berubahnya titik tumpu pada ibu hamil. Hal ini terutama karena pertambahan berat badan diperoleh selama kehamilan, dengan sebagian besar berat didistribusikan di sekitar perut. Hal ini menyebabkan pusat gravitasi ibu hamil menggeser ke depan, yang menghasilkan lebih rendah kelengkungan tulang belakangnya (Sulistyawati, 2012).

Tabel 3 menunjukkan bahwa pada kelompok perlakuan pada pengukuran awal ibu hamil yang mengalami keluhan nyeri pada symphysis pubis sebesar $45 \%$ dalam kategori nyeri ringan, setelah melakukan prenatal yoga sebanyak enam kali nyeri symphysis pubis pada ibu hamil berubah menjadi kategori tidak nyeri sebesar $45 \%$. Sedangkan pada kelompok ibu yang tidak melakukan prenatal yoga pada pengukuran awal nyeri symphysis pubis yang dialami ibu dalam kategori nyeri sedang sebesar 55\% dan setelah diukur ulang dalam enam kali kunjungan pemeriksaan kehamilan nyeri symphysis ibu hamil dalam kategori sedang meningkat menjadi $60 \%$.Selain nyeri pinggang peregangan ligament di daerah tulang kemaluan juga menyebabkan nyeri di daerah kemaluan yang biasa dikenal dengan symphysis pubis disfunction (SPD). Symphysis pubis disfunction (SPD) atau Pain Girdle Pelvis (PGP) adalah suatu kondisi yang menyebabkan nyeri pada satu atau lebih sendi panggul dan kesulitan berjalan, hal ini paling sering berhubungan dengan kehamilan (Jaim, 2016). Symphysis pubis disfunction dapat disebabkan diantaranya pada kehamilan terjadi peningkatan dalam jumlah hormone relaksin yang menyebabkan perlunakan ligament seluruh tubuh akibatnya otot-otot sekitar punggung bawah dan panggul harus bekerja lebih keras untuk mendukung tubuh dan dalam beberapa kasus sehingga mengakibatkan rasa sakit, otot panggul yang biasanya mendukung panggul tidak bekerja secara efektif seperti ketika tidak dalam kondisi hamil karena berat bayi menekan dasar panggul (Wainright, 2012).

Tabel 4 menunjukkan bahwa pada kelompok ibu yang melakukan prenatal yoga saat dilakukan pengukuran awal sebagian besar ibu hamil mengalami oedema derajat 2 sebanyak 14 responden $(70 \%)$ dan setelah melakukan prenatal yoga sebanyak enam kali terjadi perubahan yaitu sebagian besar ibu hamil mengalami oedema derajat 1 sebanyak 16 responden (80\%). Sedangkan pada kelompok ibu hamil yang tidak melakukan prenatal yoga pada saat pengukuran awal sebagian besar ibu mengalami oedema derajat 3 sebanyak 9 responden (45\%) dan setelah dilakukan pengukuran ulang setelah enam kali kunjungan kehamialn sebagian besar ibu hamil mengalami pedema derajat 2 sebanyak 7 responden (35\%). Edema adalah pembengkakan yang disebabkan oleh 
penimbunan cairan di dalam cairan tubuh. Setengah dari wanita hamil mengalami bengkak pada kaki selama kehamilannya, oedema disebabkan oleh volume darah ekstra yang berlebih selama hamil. Yoga hamil adalah latihan gerak untuk mempersiapkan ibu hamil secara fisik atau mental pada persalinan cepat, aman, spontan dan mengurangi keluhan selama kehamilan, dengan melakukan yoga hamil dapat memperlancar sirkulasi darah dan mengurangi bengkak kaki (Geri, 2011). Semakin besar usia kehamilan ibu, semakin besar edema yang dialami namun edema yang terjadi adalah edema yang fisiologis yang diakibatkan terus membesarnya rahim. Bila edema semakin besar akan mengurangi aktivitas ibu, karena beban tubuh akan bertambah. Edema dapat terjadi semakin parah bila kadar natrium tinggi dalam tubuh karena sifat natrium (garam) menarik air lebih banyak ke dalam aliran darah. Bila air terus tertarik dan pembuluh darah menjadi melebar, pembuluh darah dapat pecah dan akibat dari pembuluh darah pecah akan menghambat suplay nutrisi ke janin, bila nutrisi kurang menghambat pertumbuhan janin (Vivin, 2011).Salah satu yang dapat mengurangi edema dengan cara memperlancar sirkulasi darah adalah dengan melakukan yoga hamil. Yoga hamil salah satu manfaatnya adalah memperbaiki sirkulasi darah yang tidak lancar pada ibu hamil, sirkulasi darah yang tidak lancar dapat menyebabkan bengkak pada kaki. Dengan teratur melakukan yoga hamil cairan yang semulanya tertahan di kaki dapat dibuang melalui air kencing atau keringat. Yoga hamil merupakan latihan fisik ringan yang diperuntukkan bagi ibu hamil, latihan fisik ini dapat membantu mengurangi keluhan selama masa kehamilan, secara rutin melakukan yoga hamil dapat menurunkan stress atau khawatir ibu pada proses persalinan (Ayu, 2012).

Tabel 5 menunjukkan bahwa pada kelompok ibu yang melakukan prenatal yoga sebagian besar jenis persalinannya adalah normal sebanyak $85 \%$ sedangkan pada kelompok ibu yang tidak melakukan prenatal yoga persalinan normal hanya sebanyak 55\%.Persalinan normal adalah persalinan dengan letak belakang kepala yang berlangsung spontan dalam 24 jam yang dibagi menjadi empat kala tanpa menimbulkan kerusakan yang lebih pada anak dan ibu. Persalinan normal sering disebut sebagai persalinan biasa yang artinya kelahiran seorang bayi genap bulan dengan letak belakang kepala melalui jalan lahir alamiah dengan tenaga ibu sendiri secara spontan dalam waktu paling lama 18 jam untuk primigravida dalam kondisi ibu yang tetap sehat dengan kerusakan jalan lahir minimal menjadi maksimal apabila terjadi rupture perinea tingkat II(Achdiat, 2014).Persalinan seksio sesaria adalah persalinan melalui sayatan pada dinding abdomen dan uterus yang diambil masih utuh dengan berat janin $>1000$ gr atau umur kehamilan $>28$ minggu. Keputusan untuk melakukan persalinan seksio sesarea diharapkan dapat menjamin turunnya tingkat morbiditas dan mortalitas, sehingga sumber daya manusia dapat ditingkatkan yang tentunya disertai dengan peningkatan keadaan umum sehingga mampu menerima risiko tindakan seksio sesaria, perawatan setelah operasi dan kembalinya kesehatan secara optimal. Dengan demikian, tidak semua ibu hamil dapat melahirkan secara normal. Sebagian dari mereka ada yang mendapatkan masalah atau kesulitan untuk melakukan persalinan normal atau spontan sehingga harus mengalami persalinan secara abnormal yang salah satunya adalah seksio sesarea dilakukan(Manuaba, 2010). 
Tabel 6 diketahui bahwa ibu yang melakukan prenatal yoga mempunyai kualitas tidur yang baik sebesar $85 \%$ sedangkan ibu yang tidak melakukan prenatal yoga mempunyai kualitas tidur baik hanya $25 \%$. Hasil analisis data penelitian diperoleh nilai p-value sebesar 0,002 yang berarti bahwa ada pengaruh prenatal yoga terhadap kualitas tidur ibu hamil trimester III.Dampak dari gangguan tidur atau kurangnya kualitas tidur dapat beresiko pada janin, kehamilan dan saat melahirkan. Oleh karena itu ibu hamil yang mengalami gangguan tidur selama kehamilan dianjurkan untuk mendapatkan pantauan khusus(Nurafif, 2013).Dalam hasil penelitian Field mengatakan ibu hamil yang mengalami stress juga mengalami insomnia sehingga dapat meningkatkan tekanan darah ibu, meningkatkan resiko kehamilan bayi prematur bahkan keguguran (Tryadini, 2010). Tehnik senam yoga mengendalikan pernapasan dan pikiran. Latihan ini dapat menguatkan sistem pernapasan, menenangkan sistem saraf, membantu mengurangi dan menghilangkan kekacauan, dan dapat menguatkan sistem kekebalan tubuh. Pernapasan juga memainkan peranan penting dalam metabolisme tubuh, yaitu proses tubuh menguraikan nutrisi. Manfaat nyata yang dapat dirasakan dari latihan ini adalah berkurangnya kelelahan, pikiran dan emosi menjadi tenang Gerakan yoga yang terjadi pada tubuh diawali dengan terciptanya suasana relaksasi alam sadar yang secara sistematis membimbing pada keadaan rileks yang mendalam. Terciptanya rileksasi akan menghilangkan suara-suara dalam pikiran sehingga tubuh akan mampu untu melepas ketegangan otot. Ketika tubuh mulai rileks nafas menjadi santai dan dalam, sehingga sistem pernapasan dapat beristirahat. Melambatnya ritme pernapasan ini akan membuat detak jantung lebih lambat dan memberikan pengaruh positif terhadap keseluruhan sistem sirkulasi dan jantung untuk beristirahat dan mengalami proses peremajaan. Sistem saraf simpatik yang selalu siap beraksi menerima pesan "aman" untuk melakukan relaksasi sedangkan sistem saraf parasimpatik akan memberikan respon untuk relaksasi. Selain saraf simpatik, pesan untuk relaksasi juga diterima oleh kelenjar endokrin yang bertanggung jawab terhadap sebagian besar keadaan emosi dan fisik yang akan membuat tubuh menjadi rileks dan kualita tidur dapat meningkat (Amy, 2011).

Berdasarkan table 7 diketahui bahwa ibu hamil yang melakukan prenatal yoga sebagian besar mengalami nyeri pinggang dalam kategori ringan sebanyak $50 \%$ sedangkan ibu hamil yang tidak melakukan prenatal yoga sebagian besar mengalami nyeri pinggang dalam kategori sedang sebanyak 50\%. Hasil analisis menunjukkan bahwa p-value 0,001 yang berarti ada Pengaruh Prenatal Yoga terhadap Nyeri Pinggang Ibu Hamil Trimester III.Yoga dan senam napas merupakan olahraga yang dapat meringankan nyeri saat kehamilan. Dengan teknik ini, seorang calon ibu akan mendapatkan porsi latihan khusus untuk mencegah datangnya nyeri yang mungkin datang pada saat mengalami kehamilan. Namun, jika calon ibu sudah mengalami kehamilan, maka latihan fisik yang baik akan mampu membantu mengurangi nyeri punggung khususnya pada kehamilan trimester III(Musbikin, 2015). Kehamilan yang terjadi ini juga mempengaruhi keseimbangan tubuh karena cenderung untuk berat di bagian depan. Untuk menyeimbangkan berat tubuh maka ibu akan berusaha untuk berdiri dengan tubuh condong ke belakang (Depkes RI, 2011).Ibu akan merasakan nyeri di bagian 
pinggang pada saat terjadi perubahan postur tubuh, cara mengatasinya masalah nyeri pinggang yang diderita oleh ibu hamil adalah dengan cara latihan fisik yoga hamil secara teratur. Gerakan yoga hamil yang dilakukan pada ibu hamil yang bermanfaat untuk latihan otot-otot pinggang sehingga dapat mengurangi ketegangan otot dan menurunkan nyeri adalah tundukkan kepala sambal mengangkat bagian punggung hingga ke atas sambal menarik nafas, kemudian turunkan punggung sambal mengangkat kepala kea rah atas dan sambal membuang nafas pelan-pelan. Lakukan gerakan ini sebanyak 8x8 (Depkes RI, 2011).

Pada table 8 dapat diketahui bahwa nyeri symphisis pubis pada ibu hamil yang melakukan prenatal yoga sebagian besar dalam kategori nyeri ringan sebesar $35 \%$ sedangkan ibu hamil yang tidak melakukan prenatal yoga sebagian besar mengalami nyeri symphisis pubis dalam kategori berat sebesar $30 \%$. Hasil analisis penelitian diketahui bahwa nilai p-value 0,000 yang berarti bahwa ada pengaruh prenatal yoga terhadap nyeri symphisis pubis pada ibu hamil trimester III.Senam yoga menjadi cara yang baik untuk mempersiapkan persalinan yang dilakukan di kelas prenatal karena dalam kelas ini latihan disesuaikan dengan kondisi ibu hamil dengan berbagai pendekatan latihan peregangan, konsentrasi dan pengaturan pernapasan yang memiliki banyak manfaat bagi ibu hamil dan janinnya seperti mengurangi stress dan kecemasan, meningkatkan kualitas tidur, meningkatkan kekuatan. Fleksibilitas dan daya tahan yang diperlukan untuk persalinan, penurunan akibat sakit punggung atau nyeri symphysis pubis (Aprillia, 2011).Selain nyeri pinggang peregangan ligamen di daerah tulang kemaluan juga menyebabkan nyeri pada daerah kemaluan yang biasa dikenal dengan Symphisis Pubis Disfunction (SPD). Symphisis Pubis Disfunction (SPD) atau Pain Girdle Pelvis (PGP) adalah suatu kondisi yang menyebabkan nyeri pada satu atau lebih sendi panggul dan kesulitan berjalan, hal ini paling sering berhubungan dengan kehamilan(Jaim, 2016). Nyeri symphisis pubis saat kehamilan dapat menjadi buruk kondisinya jika tidak segera ditangani seperti kerusakan jaringan sekitar sebagai respon mal adaptif dari nyeri ditambah emosional yang kurang baik dapat terjadi, depresi dan perubahan mood merupakan masalah terbesar yang ditemukan, karena masalah ini dapat mengubah persepsi kesehatan secara umum bagi ibu hamil yang mengalami nyeri symphisis pubis, frustasi karena tidak dapat melaksanakan tugas sehari-hari sebagai seorang ibu serta komunikasi terhadap pasangan maupun keluarga menjadi kurang harmonis karena sang ibu menganggap tidak mampu merawat diri sendiri maupun keluarga dan sang ibu tidak dapat menjalani kehamilannya dengan nyaman (ACPWH, 2011).

Pada table 9 dapat diketahui bahwa sebagian besar oedema yang dialami pada kelompok ibu yang melakukan prenatal yoga dalam kategori derajat 1 sebanyak $80 \%$ sedangkan pada kelompok ibu yang tidak melakukan prenatal yoga sebagian besar mengalami oedema derajat 2 sebanyak 35\%. Hasil analisis menunjukkan p-value 0,004 yang berarti Ada Pengaruh Prenatal Yoga terhadap Oedema pada Ibu Hamil Trimester III.Edema pada ibu hamil dapat terlihat pada kehamilan 16-36 minggu atau trimester II, namun edema semakin jelas pada minggu ke 28-36 atau trimester III. Semakin tua usia kehamilan semakin besar edema kaki. Karena pada usia kehamilan yang tua janin yang dikandung semakin 
besar sehingga menekan pembuluh darah vena yang ada disekitar rahim(Sujiyatini, 2011). Berdasarkan hasil penelitian setelah melakukan prenatal yoga responden yang sebagian besar mengalami oedema dejarat 2 turun menjadi derajat 1. Menurut Eileen Brayshaw (2010) yoga hamil salah satu manfaatnya adalah memperbaiki sirkulasi darah yang tidak lancar pada ibu hamil, sirkulasi darah yang tidak lancar dapat menyebabkan bengkak pada kaki. Dengan teratur melakukan yoga hamil cairan yang semula tertahan di kaki dapat dibuang melalui air kencing atau keringat.Ibu yang belum pernah melakukan yoga hamil derajat edemanya lebih besar daripada ibu yang pernah melakukan yoga hamil selama kehamilannya, hal ini dikarenakan ibu yang pernah melakukan yoga hamil dapat melakukan atau mengulangi sendiri gerakan yang dipelajarinya di kelas yoga, berbeda dengan ibu yang tidak pernah melakukan yoga kehamilan tidak akan mengetahui bagaimana cara mengatasi edemanya.

Tabel 10 menunjukkan bahwa sebagian besar jenis persalinan pada ibu hamil yang melakukan yoga kehamilan dalam kategori normal (spontan) sebanyak $85 \%$ sedangkan sebanyak $15 \%$ dengan melalui tindakan baik secara sectio caesaria maupun vakum ekstraksi. Sedangkan sebagian besar jenis persalinan pada ibu hamil yang tidak melakukan yoga kehamilan adalah persalinan normal sebanyak 55\% sedangkan sebanyak $45 \%$ persalinannya melalui tindakan baik secara section caesaria maupun vakum ekstraksi.Jenis persalinan ibu yang mengikuti senam yoga selama kehamilan sebagian besar adalah persalinan normal, Persalinan normal adalah persalinan dengan letak belakang kepala yang berlangsung spontan dalam waktu 24 jam yang dibagi menjadi empat kala tanpa menimbulkan kerusakan yang lebih pada anak dan ibu. Persalinan normal sering disebut sebagai persalinan biasa yang artinya kelahiran seorang bayi genap bulan dengan letak belakang kepala melalui jalan lahir alamiah dengan tenaga ibu sendiri secara spontan dalam waktu paling lama 18 jam untuk primigravida dalam kondisi ibu yang tetap sehat dengan kerusakan jalan lahir minimal menjadi maksimal apabila terjadi rupture perinea tingkat II (Achdiat, 2014).Penyulit pada saat persalinan dapat di cegah dengan latihan olahraga dan relaksasi yang mana hal tersebut dapat diperoleh melalui yoga kehamilan Karena yoga merupakan suatu olah tubuh, pikiran dan mental yang sangat membantu ibu hamil dalam melenturkan persendian dan menenangkan pikiran terutama pada ibu hamil trimester III . Yoga merupakan salah satu cabang olahraga yang sangat baik bagi ibu hamil, yoga kehamilan merupakan modifikasi dari olahraga senam yang disesuaikan gerakannya dengan kondisi ibu hamil (Indiarti, 2012). Melalui yoga ibu hamil akan rutin bergerak sehingga dapat mempercepat persalinan normal, hal tersebut sesuai dengan teori yang menyatakan bahwa ibu hamil yang sering bergerak selama hamil akan dapat mempengaruhi (mempercepat) proses persalinan (Indiarti, 2012).

Pada table 11menunjukkan hasil bahwa variabel yang paling dominan dari pengaruh prenatal yoga terhadap ketidaknyamanan ibu hamil trimester III adalah variabel Nyeri Symphisis Pubis, hasil analisis didapatkan Odds ratis (OR) dari variabel nyeri symphysis pubis responden 6.030 artinya bahwa ibu yang mengikuti prenatal yoga tidak akan mengalami nyeri symphysis pubis 6 kali lipat dibandingkan ibu yang tidak mengikuti prenatal yoga. Nyeri sympisis pubis 
merupakan keluhan subyektif yang ditandai dengan adanya sekumpulan tanda dan gejala tidak nyaman di daerah pelvis, termasuk nyeri pelvis yang menjalar sampai ke paha atas dan perineum yang dapat membatasi pergerakan. 20-50\% ibu hamil mengeluhkan nyeri pelvis hingga usia kehamilan 30 minggu dan semakin banyak prevalensinya berdasarkan paritas(NHS, 2014). Beberapa faktor risiko yang menyebabkan nyeri sympisis pubis diantaranya adalah usia ibu hamil, riwayat nyeri sebelumnya, tingginya IMT, pendidikan ibu yang rendah, kondisi emosional yang kurang baik, pekerjaan fisik yang berat, merokok dan jarang berolahraga(Larsen, 2013).

\section{Simpulan}

\section{SIMPULAN DAN SARAN}

Ada pengaruh prenatal yoga terhadap kualitas tidur $(0,002<0,005)$, nyeri pinggang $(0,001<0,005)$, nyeri symphysis pubis $(0,000<0,005)$, oedema $(0,004<0,005)$, jenis persalinan $(0,038<0,005)$. Variabel yang paling dominan dari pengaruh yoga terhadap ketidaknyamanan dalam kehamilan trimester III adalah nyeri symphisis pubis (OR 6,030).

\section{Saran}

Bagi ibu hamil dari hasil penelitian ini diharapkan dapat menambah wawasan tentang cara pengurangan ketidaknyamanan dalam kehamilan sehingga ibu hamil dapat menjalani kehamilan yang sehat. Bagi tenaga kesehatan diharapkan dapat meningkatkan kemampuan untuk melakukan prenatal yoga sehingga dapat membantu ibu hamil untuk mengurangi ketidaknyamanan dalam kehamilan.

\section{DAFTAR PUSTAKA}

Achadiat, Chrisdioni, M. (2014). Prosedur tetap Obstetri dan Ginekologi. Jakarta: EGC.

Amy E. Beddoe I and Kathryn A.Lee. (2011). Mind-Body Interventions During Pregnancy. JOGNN. (diakses 25 Agustus 2019).

Aprillia, Y dan Ritchmond, B. (2011). Gentle Birth: Melahirkan Nyaman Tanpa Rasa Sakit. Jakarta: PT Gramedia Widiasarana Indonesia.

Association of Chartered Physiotherapist In Woman Health. (2011). Pregnancy Related Pelvic Girdle Pain Formerly Known As Symphisis Pubis Disfunction ACPWH.

Ayu Sekar. (2012). Kursus Kilat Senam Hamil. Yogyakarta: Araska.

Bobak, I, M, Lowdermilk, D, \& Jensen, M, D. (2010) Keperawatan Maternitas. Alih Bahasa Wijayarini, M.A\& Anugerah, P.I. Edisi 4. Jakarta: EGC.

Community Practitioner. (2011). Pregnancy Part Seven : Minor Discomforts and Medical Complications. Proquest Nursing \& Allied Health Source.

Departemen Kesehatan RI. (2011). Pedoman Pelayanan Antenatal di Tingkat Pelayanan Dasar. Jakarta: Depkes RI.

Eileen Brayshaw. (2010). Senam Hamil \& Nifas Pedoman Praktik Bidan. Jakarta: EGC 
Fauziah, Lestari. (2016). Efektivitas Latihan Yoga Prenatal dalam Menurunkan Kecemasan pada Ibu Primigravida Trimester III. Bandung: Universitas Padjajaran.

Field T., Diego M., Rief M.H., Figueiredo B, Schan B.S., amd Khun C. (2006). Sleep Disturbansces in Depressed Pregnant Women and Their Newborns. Infant Behavior and Development, 30 (2010) : 127-13

Geri, Morgan. (2011). Obstetri dan Ginekologi. Jakarta:EGC.

Hamilton. (2010). Dasar-Dasar Keperawatan Maternitas. Jakarta: EGCAnggraeni Dyah. (2012). Melahirkan Tanpa Rasa Sakit. Yogyakarta

Indiarti. (2012). Panduan Lengkap Kehamilan, Persalinan dan Perawatan Bayi. Yogyakarta: Dislogia Media

Jaim, S. (2016). RCOG Review: Symphisis Pubis Disfuntion A Practical Approach ti Management (diakses 25 Agustus 2018).

Larsen EC, Wilken-Jensen C, Hansen A, Jensen DV, Johansen S, et al. (2013). Symptom-giving pelvic gridle relaxtion in pregnancy: invisible factors acta obstet agynecol Scand (diakses 29 Agustus 2018)

Manuaba, I.B.G. (2010). Ilmu Kebidanan, Penyakit Kandungan dan KB untuk Pendidikan Bidan. Jakarta: EGC.

Musbikin. (2015). Panduan Ibu Hamil dan Melahirkan. Jakarta: Mitra Pustaka

National Health System. (2014). Pelvic Pain in Pregnancy. http://www.nhs.uk/Conditions/pregnancy-and-baby/Pages/pelvic-painpregnant-spd.aspx (diakses 02 Juli 2018)

National Sleep Foundation. (2017). Pregnancy and Sleep. Available at: http://sleepfoundation.org/sleep-topics/pregnancy-and-sleep

Nurafif, A.H.(2013). Aplikasi Asuhan Keperawatan berdasarkan diagnosis NANDA NIC NOC. Jogjakarta: Mediaction

Potter, P.A \& Perry, A.G. (2010). Buku Ajar Fundamental Keperawatan : Konsep, Proses dan Praktis. (Renata Komalasari, et al, Penerjemah). Edisi: Ke 4. Jakarta : Penerbit Buku Kedokteran EGC.

Sujiyatini. (2011). Perawatan Ibu Hamil (Asuhan Ibu Hamil). Yogyakarta: Fitramaya

Sulistyawati, A. (2012). Asuhan Kebidanan pada Masa Kehamilan. Jakarta: Salemba Medika.

Triyadini, Asrin, Upoyo. (2010). Efektifitas Terapi Massage dengan Terapi Mandi Air Hangat terhadap Penurunan Insomnia Lansia. Vol. 5 No.3

Varney, H. (2011). Buku Ajar Asuhan Kebidanan. Jakarta: EGC.

Venkata C And Vankatashihan. S.B. (2010). Sleep Disorders Breathing During Pregnancy. The Journal of the American Board of Family Medicine, 22 (2) : $158-168$.

Vivin, Nani. (2011). Asuhan Kehamilan untuk Kebidanan. JakartaL Salemba Medika

Wainright, M. Et al. (2012). Symphisis Pubis Dysfunction: Improving the Service. British Journal of Midwifery Vol. 11 No. 11 (diakses 10 Juli 2018).

Yucel Sebnem. C, dkk. (2012). Sleep Quality And Related Factors In Pregnant Women. Journal of Medicine And Medical Sciences. Vol. 3 (7). 459-463. 